\title{
Normative and Legal Regulation of Non-State Archives
}

\author{
MIKHAIL V. LARIN, DR. PROF. \\ Head of the Department of electronic records management systems, Historical and Archival Institute of the Rus- \\ sian State University for Humanities (RGGU), Tel: +7 495 628-52-97, mobile: +7 910421 05 29, GSP-3, Miuss- \\ kaia pl. 6, Russia, Moscow, 125993 \\ e-mail:mik091947@gmail.com; asdou@rggu.ru
}

\section{Normative and Legal Regulation of Non-State Archives}

\begin{abstract}
Questions of normative and legal regulation of non-state archives activity on the example of the Russian Federation are examined in the article. In modern conditions non-state archives became an integral part of archival system. The author has made an attempt to present development of non-state archives, as far as their normative and legal regulation and organization of activity are concerned. Systematization of types of non-state archives is given. There are archives of business organizations, political parties and public associations, churches, universities, private multi-disciplinary archives, personal archives, pointed out in this work. Examples of non-state archives' activity are shown, which are valuable for preservation of documentary heritage.
\end{abstract}

Key words: documents, state archives, private archives, archives of business, archives of political parties and public associations, archives of church, university archives

\section{Regolamentazione normativa e legale degli archivi non statali}

\section{SINTESI}

Vengono esaminate nell' articolo le problematiche relative al Regolamento normativo e giuridico degli archivi non statali sull'esempio della Federazione Russa. Nell' attuale situazione gli archivi non statali sono diventati parte integrante del sistema archivistico. L'autore ha tentato di presentare lo sviluppo attuale degli archivi non statali, per quanto riguarda il loro regolamento normativo e giuridico e l'organizzazione delle attività. Viene dato conto della sistematizzazione delle tipologie di archivi non statali. Sono esemplificati nel presente lavoro archivi di organizzazioni imprenditoriali, partiti politici e associazioni pubbliche, enti ecclesiastici, Università, archivi privati multi-disciplinari, archivi personali. Vengono inoltre presentate le specifiche attività di archivi, preziosi per la conservazione del patrimonio documentario.

Parole chiave: documenti, Archivi di Stato, archivi privati, archivi d'impresa, archivi di partiti politici e associazioni pubbliche, archivi ecclesiastici, archivi universitari

Normativne in zakonske uredbe nedržavnih arhivov

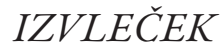

$\mathrm{V}$ prispevku avtor obravnava vprašanja normativne in pravne ureditve dejavnosti nedržavnega arhiva na primeru Ruske federacije. V sodobnih razmerah so nedržavni arhivi postali sestavni del arhivskega sistema. Avtor je poskušal predstaviti razvoj nedržavnih arhivov, kar zadeva njihovo normativno in zakonsko ureditev ter organizacijo dejavnosti. Podana je sistematizacija vrst nedržavnih arhivov. Obstajajo arhivi poslovnih organizacij, političnih strank in javnih združenj, cerkva, univerz, zasebnih multidisciplinarnih arhivov, osebnih arhivov. Prikazani so primeri dejavnosti nedržavnih arhivov, ki so pomembni za ohranjanje dokumentarne dediščine.

Ključne besede: dokumenti, državni arhivi, zasebni arhivi, poslovni arhivi, arhivi političnih strank in javnih združenj, cerkveni arhivi, univerzitetni arhivi 
Нормативно-правовое регулирование деятельности негосударственных архивов

\section{АННОТАЦИЯ}

В статье раскрываются вопросы нормативно-правового регулирования деятельности негосударственных архивов на примере Российской Федерации. В современных условиях негосударственные архивы стали неотъемлемой частью архивной системы. В статье сделана попытка преАставить вопросы развития негосударственных архивных образований с точки зрения их нормативно-правового регулирования и организации деятельности. Приводится систематизация типов негосударственных архивов. Выделены архивы бизнес-организаций; политических партий и общественных объединений; архивы церкви; университетские архивы; частные многопрофимьные архивы; Аичные архивы. Ааны примеры организации деятельности негосударственных архивов, обосновано их значение Аля сохранения документального наследия.

КАючевые слова: документ, архивный документ, государственный архив, негосударственные архивы, бизнес-архивы, архивы политических партий, архивы церкви, университетские архивы

\section{Introduction}

Relationship of the state and archives of non-state organizations is an object of research of scientists and experts from different countries. These questions are especially actual for states with historical transformations as the result of changes of social system, forms of ownership, administrative organization. It was impossible to speak about non-state archives thirty years ago, for example, in the Soviet Union, because of their absence. Nowadays non-state archives became an integral part of an archival landscape of Russia. In this paper we will try to enlighten questions of development of non-state archival entities from the point of view of their normative and legal regulation and activity.

Private archives developed during the pre-Soviet period of Russia. They can be divided into privately owned funds (storage of materials of manors, offices on manors management, publishing houses) and into personal archival funds (consists of documents, produced in the course of one person' life and activity).

Under socialism all archives were under centralized administration of the state. After the Soviet Union disintegration and change in constitutional bases of functioning of its assignee - the Russian Federation, there was again multi - sectoral economy with its development of property privatization, and, as a result, emergence of so-called non-state part of national economy in the country. As records management is an integral part of any economic activity, there was a need of archival storage of business documentation in private organizations. The Russian archival legislation includes a norm, according to which organizations and citizens have the right to create archives to store archival documents, formed in the course of their activity, including the aim of storage and use of archival documents, not relating to state or municipal ownership.

For this purpose archives, different in their dependence on professional profile, are created in the organizations. According to legislation, archives is an establishment or structural division of organization, carrying out storage, acquisition, control and use of archival documents.

The analysis allows us to define the main types of archives:

- archives of business organizations;

- archives of political parties and public associations;

- archives of church;

- university archives;

- private multi-disciplinary archives;

- personal archives.

Despite the variety of organizational forms of non-state archives, they are working according the uniform legislative basis. 


\section{Legislative regulation of non-state archives}

In article 1 of the Federal law "About archival activity in the Russian Federation" it is accurately stated, that it governs the relations in storage, acquisition, control and use of documents of the Archival fund of the Russian Federation and other archival documents, irrespective of their ownership forms.

The Archival fund of the Russian Federation consists of archival documents, which are stored in the territory of the Russian Federation, irrespective of their original source, time and creation method, type of carrier, ownership forms and a place of storage. Incorporation of privately owned documents into the structure of the Archival fund of the Russian Federation is carried out on the basis of documents' appraisal, and made out by the contract between the owner of archival documents and state or municipal archives. This contract includes obligations of the owner of archival documents on storage, control and use of documents of the Archival fund of the Russian Federation.

It is considered as private property according to the Law the archival documents of organizations, operating in the territory of the Russian Federation, not being state or municipal, including public associations from the date of their registration. And also the archival materials, created by citizens or lawfully acquired by them, according to the legislation of the Russian Federation on public and religious associations.

The Federal law states, that the archival documents, which are in the state or municipal ownership, are not subject to privatization, cannot be an object of sale, exchange, donation and also other transactions, led to their alienation, if otherwise is not provided by international treaty of the Russian Federation or federal laws. Even in case of privatization of state or municipal enterprises, the archival documents, formed in the course of their activity, including those ones on staff, remain in federal property, in property of the subject of the Russian Federation and municipal property.

In article 11 of the Law on archival activity "Peculiarities of civil documents' cycling of the Archival fund of the Russian Federation, which are in private property" the rights and duties of private owners in relation to this category of archival documents are presented. Documents of the Archival fund of the Russian Federation, which are in private property, can be alienated or pass from one person to another as the universal succession or otherwise. Thus, an assignee, in 30-days period of time, from the date of alienation or transition of rights, is obliged to notify state or municipal archives, museum, library or scientific organization, with which the former owner - an acquisition source - signed the contract, on transition of the owner rights to the assignee. Upon transition of owner rights to privately owned documents of the Archival fund of the Russian Federation, to other person, all the duties, specified in the contract, provided by the Federal law, passed to this person.

The Law contains special norms, concerning especially valuable documents and those, protected by state. If owner does not fulfill obligations on storage, control and use of these documents, which can lead to loss of their value, such documents could be withdrawn from this owner by court decision and according to article 240 of the Civil code of the Russian Federation. In case of tendering on sale of privately owned archival documents, organizers of tendering are obliged not later than 30 days till the sale day to inform administrative bodies on archival activity about place, time and terms of archival documents sale in writing form.

Documents of the Archival fund of the Russian Federation, which are privately owned, can be stored by owners independently or can be transferred for storage to state or municipal archives under contract. Thus, storage conditions of these documents are defined by their owners, according to the standards of archival Law.

Non-state organizations provide selection and transfer of their properly owned archival documents, referred to federal or municipal property, property of the subject of the Russian Federation, to state and municipal archives in ordered state. At liquidation of non-state organizations, including as a result of bankruptcy, the archival documents, produced in the course of their activity and included into structure of the Archival fund of the Russian Federation, personal documents, and also the archival documents, which retention period of their temporary storage hasn't been expired, are transferred by liquidator or competitive manager in the ordered state for storage to relevant state or municipal archives on the basis of the contract between the liquidator or competitive manager and state or municipal archives. A liqui- 
dator or competitive manager will organize ordering of archival documents of liquidated organization, including an organization - bankrupt.

Owner of archival documents sets the terms of access to the properly owned documents, except those, access to which is regulated by the legislation of the Russian Federation.

\section{Archives of business organizations}

Archives is an element of organizational structure of any large organization, engaged in business. The most important organizations are sources of acquisition of state and municipal archives, others are managing their archives independently. As a rule, in the exercise of activity' organization archives of business organizations are regulated by the Federal Law "About archival activity in the Russian Federation" and by Rules of storage .... So, norms of the Law are obligatory for them, and the Rules are used as recommendations. However, taking into account historical traditions, archives of business organizations prefer to follow the terms of Rules during their activity.

Nowadays business activity is considered as an integral element of economic development of society, so special attention has to be paid to study of culture and practical management, to understanding of the role and possibility to include business archives into control process, mechanism of interaction of archives with other units of firm. Along with other units archives can be directly involved in commercial activity, being functionally and structurally integrated into the system of records keeping, information and commercial services. The view point of organization's administration is changing, as far as the importance of archives' role, and also significance of activity of archivists with their professional skills in analysis and assessment of processes and phenomena, associated with collection, storage and use of commercial organizations' documents. It is also important now to realize scientific and practical value of preservation of documentation on campaign history.

Let's consider the activity of similar archives on a concrete example of State corporation on atomic energy "Rosatom", which was created instead of the Federal agency on atomic energy. In 2004 the Ministry of the Russian Federation on Atomic Energy was replaced, and in 2007 State corporation on atomic energy "Rosatom" was formed. This corporation includes organizations and enterprises of the country nuclear branch. One of the functions, assigned to the corporation, is depository storage of documents of the Archival fund of the Russian Federation. There is a contract "On terms and conditions of depository storage and use of documents of the Archival Fund of the Russian Federation, which are in the federal property" between the Federal Archival Agency and Rosatom State corporation. According to the contract the term of depository storage of the documents of the Archival fund of the Russian Federation in the archives of Rosatom State corporation is 100 years.

In 2009 in order to fulfill the function on depository storage of documents of the Archival fund of the Russian Federation the Rosatom State corporation board made the decision on creation of private institution "The central archives of nuclear branch ("Tsentratomarkhiv"). The main objective of "Tsentratomarkhiv" is storage, acquisition, control and use of archival documents on nuclear branch development history. The activity of "Tsentratomarkhiv" includes preservation, acquisition, control and use of archival documents of nuclear branch, including documents of the Archival fund of the Russian Federation, referred to federal property and being on depository storage in "Tsentratomarkhiv", according to the federal laws. This institution solves social and legal queries of citizens, connected with social protection of citizens, providing pension system, and also getting privileges and compensations, according to the legislation of the Russian Federation and international obligations of the Russian Federation.

"Tsentratomarkhiv" is situated in the reconstructed building of former warehouse in Mytischi of the Moscow region. Its rooms' equipment are completely conformed to all requirements, imposed to archival storage of documents. The total area of operating archival depositories, apart from office rooms, is 2023 sq. $\mathrm{m}$ and total length of archival shelves is $12143 \mathrm{~m}$. There are 405000 units of storage, preserved in "Tsentratomarkhiv".

Being the branch archival operator, "Tsentratomarkhiv" develops and introduces normative documents in archival activity at the enterprises of the branch, which also maintain their archives. Employees of "Tsentratomarkhiv" annually carry out inspections of archival activity in the branch organizations. Traditionally once a year "Tsentratomarkhiv" organizes Branch conference of Rosatom corporation ar- 
chivists. All heads of archives and archivists of the branch from many cities of Russia participate in this event. At the conferences colleagues have an opportunity to discuss actual tasks, set for archival services of branch by Rosatom State corporation and to develop and solve uniform organizational and methodical problems.

There are a lot of similar examples of archival activity of business organizations in Russia. Many business archives are much better organized, than state archives in technical capabilities and characteristics. First of all, these are the following archives: bank archives, Pension fund archives, large enterprises of oil and gas complex archives, metallurgical enterprises archives. For example, the archives of Polar branch of mining and metallurgical plant "Norilsk nickel" occupies the area of $750 \mathrm{sq} . \mathrm{m}$.

The main objective of the archives is to preserve 500000 files. Annually the staff of this archives works with more than 4000 inquiries of citizens and prepares more than 18000 archival inquiries. There are fire and security alarm systems, a new electric equipment and lighting, new storage systems - mobile shelves, unique forced-air and exhaust ventilating Swiss devices, which give air to repository, clearing it of dust and gas ${ }^{1}$, in the archives.

\section{Archives of political parties and public associations}

During the Soviet period of the Russian history the Communist party of the Soviet Union had an extensive network of archives. Often these archives possessed much better equipment than state archives, and, as a rule, they were placed in the buildings, specially built according to the standard project. Resolutions, decisions and other materials of party forums, meetings and many other documents were stored in archives of party organizations. Now the archives of the Communist party of the USSR are integrated into general archival system of the Russian Federation.

After the USSR collapse and reorganization of political system in Russia under democratization of public life a number of parties, social movements, funds and other civil organizations were formed. Modern archives of political parties store the following documents: documents on personnel, office editions, other documentation, concerning the party activity. As a rule, the archives of political parties transfer their documents to state and municipal archives for storage. The largest parties contribute the most important archival documents to the funds of archives of federal level, keeping generally current documentation in their archives. According to the same rules, archives of trade-union organizations functions.

There are special archives, such as Gorbachev - Fund and Yeltsin - Center, the archives of the first presidents of the USSR and the Russian Federation. The archival and museum complex Gorbachev Fund is a structural unit of fund, including an archives, a library, a reading room and an exposition center.

The collection of the archives consists of personal funds, documents collections and archives of actually Gorbachev-Fund, reflecting development of the Russian state and society, generally from the end of the $1980^{\text {th }}$ till now. Documentary complex is based on the materials, donated by Gorbachev' family and members of their close surroundings. These are the following documents: first of all, a collection of M. S. Gorbachev materials; documents, reflecting his activity as the Secretary General of the Central Committee of CPSU and the President of the USSR, and also characterizing its political and public work during the period from 1992 till the present. The separate collection is made by the fund, including a collection of documents about life and activity of R. M. Gorbacheva (his wife).

All the variety of modern documentation - text, electronic, audiovisual materials - is presented in the archives. The most valuable is a collection of photos from the personal fund of M. S. Gorbachev, which includes over 30.000 units of storage and gives a wide panorama of the USSR life and modern Russia for the last 25 years. The archives of Gorbachev-Fund also includes materials of research projects of the Fund, accumulated during its existence, including materials of Round tables, conferences and other events. The reference book of this complex is an integrated reference system in the form of a database and uniting electronic catalogs of library and archives, and which also allows in online regime to provide scientific and technical processing, description, systematization of incoming documentary, photo, audio-, video and printing materials.

All rooms of archives and library are equipped with modern special archival and library equipment, where one can easily place audio, video, photographic materials, books and periodicals. It includes shel- 
ves, like "Kompaktus" on $1.152 \mathrm{rm}$, boxes for long-term storage of archival materials, made of acid-free cardboard, etc. The rooms are equipped with a fire-prevention alarm system, air conditioning system, providing regulation of temperature and humidity regime. The staff of this center is 4 persons: head, his deputy, archivist and senior librarian. Employees are provided with modern computer, copy, photo, audio-and video equipment (including equipment for digitization of video-records) ${ }^{2}$.

There is one more interesting form of archives, that is a project on creation of independent public organization "National archives", which was formed in 1988 at the Moscow State Historical and Archival Institute. It aimed at acquisition of documents on life of the USSR ordinary citizens for storage. "National archives" represented an alternative to the state archives system as it accepted for storage the sources, reflecting individual life of each person.

At first "National archives" was situated at the complex of buildings of Historical and Archival Institute of the Russian State University for Humanities, but it was independent of it. "National archives" was financed by the fund "Cultural initiative". Its work was carried out in several directions: collection, processing and storage of personal funds of the USSR citizens, collecting documents of numerous political and religious, ecological, cultural and other public organizations, which appeared and broke up in a huge number in all republics of the USSR. And, besides, letters of simple citizens in editorial office of newspapers and magazines were accepted for storage. The archival staff also worked at oral history - interviewed and made videos. The interesting feature of "National archives" is that employees refused to select documents for storage, using a criterion of appraisal as their guide. Each document, considered as important, was accepted for storage, according to the opinion of a fund-creator. Documents were taken to archives in the form of scattering, often fragmentary, not in the form of files: letters, photos, video-documents, films, sound recordings, diaries, notes, art and scientific works, drawings, graphics, photo albums since the end of XIX till the $90^{\text {th }}$ of XX century.

Ten years later after its creation "National archives" had financial problems, and in 2006 it was decided to transfer collected documents for storage to the Russian state archives of contemporary history. The transferred archives totals about 300.000 storage units on paper, 40.000 photos and drawings, some hundreds of audio and video documents. It is obvious, that "National archives" is a huge complex of documents on various carriers, having great importance as a source on history of ordinary citizens' life in the USSR and which became new experience in organization of archival activity.

\section{Archives of church}

Archives of various religions are treated as non-state (departmental) archives. The Russian orthodox church (RPTs) forms the archives of different level: archives of the Moscow patriarchy, archives of Synod institutions, diocesan archives, private archives of bishops and priests are included into this type of archives. During the Soviet era such religious organization as the Russian orthodox church was under control of public authorities. Records management was held at the high level, regular transfer of files from archives of the Council for RPTs affairs into the Central state archives of RSFSR (later the State archives of October revolution) in the Council for the Russian Orthodox Church activities, as well as, the Council for Religious Affairs.

And, besides, official archival funds of the Moscow Patriarchy and other Synod structures of the Russian orthodox church, there are also other archives of church organizations: spiritual schools of the Russian orthodox church, archives of monasteries and diocesan agencies. A secretary of diocesan agency is engaged in the work with archives of diocesan agency, and most often a clerk, who carries out current records management of diocesan agency and in parallel is engaged in the archival work, connected with archival inventory, preparation of indexes and other activities, which is extremely necessary for saving documents, reflecting operations of the diocese and the bishop. Diocesan archives mostly contain not only official documents, but also private archives of the bishops, running the diocese; photos, personal correspondence and other documents, not only concerning activity of the ruling bishop, but also secretary of diocesan agency, priests of the diocese, personnel of diocesan agency, hierarchal house and spiritual schools ${ }^{3}$.

\footnotetext{
2. http://www.gorby.ru/archival/archive_library/.
}

3. Онищенко А. Б. Церковные архивы - важный источник изучения жизнедеятельности Русской Православной Церкви в Советский период истории России. http://www.bogoslov.ru/text/1902911.html. 


\section{University archives}

In modern Russia university archives appeared among non-state archives. Let's look at the activity of university archives on the example of Scientific and educational center "Humanitarian archives" of the Russian State University for Humanities - a unique center for storage of documentary collections and personal archival funds, connected with history of the Moscow State Historical and Archival Institute (MGIAI), creation and development of RGGU and its scientific departments. The humanitarian archives is for storage, scientific description, study and publication of documentary materials, for preparation of collections "Bulletin of RGGU Humanitarian archives" for edition. The composition of documentary materials of archives for June 15, 2018 is the following: 25 funds, 6.556 units of storage. There are documentary collections on history of RGGU scientific schools, personal funds of the dead and living scientists of RGGU in the funds of Humanitarian archives. The archives carries out the work on acquisition of funds and collections of scientific centers, chairs and other scientific departments of University, and also personal funds of scientists-humanitarians of RGGU.

Similar archives are organized in some other universities. For example, the archives of the Higher School of Economics (NIU VShE) also includes personal funds of university personnel in its archives, which is a unique source of information for future generations of researchers. In 2012 the State Archives of the Russian Federation (GARF) included the Higher School of Economics into the list of acquisition sources, having confirmed the importance of university documents for history and science and having suggested to fill it up also with the documents of personal origin of scientists and researchers of the Higher School of Economics.

\section{Private multi-disciplinary archives}

In 1998 the first non-state commercial archives was formed in Russia, which on the basis of outsourcing, carried out depository storage of documents. The OSG company offered services on extra office storage of documents in the market, which were interesting to business. The foreign (mainly, western) commercial organizations, already familiar with similar technologies, became the first companies, who were consumers of such services in Russia. Now there are more than 100 archival companies only in Moscow, which besides archival processing of documents, is also engaged in depository storage of documents.

The total number of documents, stored in commercial archives, is tens of millions of files. The total turnover of only four leading Russian archival companies for 2010 exceeded 1,5 billion rubles and is almost equal to the budget of all state archival branch in the Russian Federation. The size of the market of non-state archival services only in the central part of Russia, according to expert review, is more than 30 billion rubles and annually increases in geometrical progression. It is important to state, that during last years the Federal Archival Agency promotes liberalization of this branch and creation of market competitive relations in every possible way.

From a total number of acting organizations in the Russian Federation there are more than $2 \mathrm{mln}$ organizations of different forms of ownership, which are included into a list of acquisition sources of state and municipal archives. Only 110.000 organizations transfer their documents for permanent storage. Other organizations - about $95 \%$ of its number - as a rule, are not of great attention for state and municipal archives. So, the documents of temporary storage, formed in activity of these organizations, are a very perspective field for activity of private companies.

At document transfer on depository (extra office) storage of the third-party organization, an owner of documents must provide reliable protection of them.

As an example let's look at the work of one of the largest Russian archival companies of full cycle "Delis Archives". This company works at the market of archival services more than 17 years. During this time a number of company's clients reached nearly 10.000 individuals and legal entities.

The area of archival depositories is about 11 sq. $\mathrm{m}$, there are over 1 million boxes with documents on shelves there. The company fulfills a full range of archival services, including traditional services on archival processing and cover of documents, development of nomenclature, storage and destruction of documents with expired retention periods. And, besides, "Delis Archives" is engaged in elaboration and deployment of technological decisions on digitization of documents and creation of electronic archives. 


\section{References}

1. Приказ Министерства культуры РФ от 31 марта 2015 г. N. 526 (зарегистрирован Минюстом России 7 сентября 2015 г.) «Об утверждении Правия организации хранения, комплектования, учета и использования документов архивного фонда Российской Федерации и других архивных документов в органах государственной власти, органах местного самоуправцения и организациях». Available at: http://www.garant.ru/products/ipo/prime/doc/71083090/.

2. Digital Strategy, National Archives of Great Britain: http://www.nationalarchives.gov.uk/documents/the-national-archives-digital-strategy-2017-19.pdf.

3. Cvelfar, B. (2016). On Our Way to Slovenian Digital Archives. - In: Alma Mater Europaea. $5^{\text {th }}$ International Scientific Conference: All about People: Interdisciplinarity, Transnationality and Building Bridges. Book of abstracts. - Maribor. - 2017. -March 10-11., pp. 255-256.

4. U.S. National Archives and Records Administration Fiscal Year 2014-2019: https://www.archives.gov/files/ about/plans-reports/strategic-plan/2013/nara-strategic-plan-2014-2019.pdf.

5. Онищенко А. Б. Церковные архивы - важный источник изучения жизнедеятельности Русской Православной Церкви в Советский период истории России: http://www.bogoslov.ru/text/1902911.html.

6. Журкина А.А. «Народный архив» как новая форма организации архивного дела: http://www.radnews. $\mathrm{ru} /$ народный-архив-как-новая-форма-орга.

7. Кюнг П.А. Законодательное регулирование деятемьности архивов коммерческих организаций // Справочник секретаря и офис-менеджера. 2009, N. 4. С. 34-38.

8. Рыков А.В.Эволюционное развитие негосударственных архивов в России: www.archiv.nnov.ru/?id=4713.

9. Федеральный закон от 22.10.2004 N.125-Ф3 «Об архивном деле в Российской Федерации: http://archives.ru/documents_fz_zakon-archivnoe.

10. Артизов А.Н. «Об итогах работы Федерального архивного агентства и подведомственных ему учреждений за 2009 г. и задачах на 2010 г.» Аоклад на расширенном заседании комлегии Росархива 26 феврамя 2010 г. : http://archives.ru/coordination/koll/doclad260210.shtml.

\section{SUMMARY}

Archives of the Russian Federation are divided in state and non-state archives. Development of non-state archives as an important part of archival system of the Russian Federation is presented in this report. The analysis of legislation showed a sufficient level of legal support of non-state archives activity. The following main types of non-state archives are revealed: archives of business organizations; political parties and public associations; archives of church; university archives; private multi-sectoral archives; personal archives. There are examples of activity of non-state archives, their value for preservation of documentary heritage in this work. According to contents and character of information non-state archives, perhaps, are more interesting to researchers, as they contain not only boring office documents, legal acts, official correspondence, but also photos and letters of personal character, unpublished diaries and memoirs.

Typology: 1.02 Review article

Submission date: 14.07.2018

Acceptance date: 08.08.2018 